\title{
Biomimetic calcium carbonate with hierarchical porosity produced using cork as a sustainable template agent
}

\author{
Francesca Scalera $^{\mathrm{a}}$, Luigi Carbone ${ }^{\mathrm{a}}$, Simona Bettini ${ }^{\mathrm{b}}$, Robert C. Pullar ${ }^{\mathrm{c}}$, Clara Piccirillo $^{\mathrm{a}, *}$ \\ ${ }^{\text {a }}$ CNR NANOTEC, Institute of Nanotechnology, Campus Ecotekne, Lecce, Italy \\ ${ }^{\mathrm{b}}$ Department of Innovation Engineering, Campus Ecotekne, University of Salento, Lecce, Italy \\ ${ }^{\mathrm{c}}$ Department of Engineering of Materials and Ceramics/CICECO - Aveiro Institute of Materials, University of Aveiro, Aveiro, Portugal
}

\section{A R T I C L E I N F O}

\section{Keywords:}

Calcium carbonate

Cork

Porosity

Biomimetic

Environment remediation

\begin{abstract}
A B S T R A C T
Calcium carbonate has many applications in different fields; its use in environment remediation is particularly considered, due to its non-toxicity and potentially high efficiency. The structure, morphology and surface features of calcium carbonate can greatly affect its performance. Hierarchical porosity, in particular, can be beneficial for several functional properties. In this study, we report the synthesis of biomorphic calcium carbonate using a sustainable template agent - waste cork powder. Pyrolysed cork powder was infiltrated by an appropriate calcium-containing salt and successively thermally treated. Selected precursors, different impregnationsolution concentrations and thermal conditions were tested. The resulting materials were characterised by XRD, Raman spectroscopy and SEM. Surface area and porosity features were studied by BET analysis, with a detailed study on the effect of synthesis on the mesoporosity of the materials, average sizes varying between $4-15 \mathrm{~nm}$. The most valuable results were achieved with calcium acetate followed by pyrolysis performed for relatively short time period. This maintained the porous 3D honeycomb cork structure made of $\sim 20 \mu \mathrm{m}$ hexagonal cells, while consisting of highly mesoporous single-phase $\mathrm{CaCO}_{3}$. Such samples showed the highest surface area ever reported for $\mathrm{CaCO}_{3}$ prepared using a plant-based template; moreover, it also exhibited a dual-scale hierarchical porosity as, in addition to micrometer scale cellular macroporosity, it contained a significant mesoporosity in the cell walls, with a very narrow range of $3.6-3.9 \mathrm{~nm}$.

These promising characteristics enable the potential employment of cork-derived $\mathrm{CaCO}_{3}$ for environment remediation.
\end{abstract}

\section{Introduction}

Calcium carbonate $\left(\mathrm{CaCO}_{3}\right)$ is a very important mineral compound. It is present in many living organisms, and its functions include structural support (i.e. bones) and protection (i.e. shells) [1]. This compound also has many industrial applications, for instance as a filler for plastics, paper or rubber, or in building materials [2]. Calcium carbonate usage for environment remediation is considered with growing interest, as $\mathrm{CaCO}_{3}$ is quite biocompatible, and hence it does not pose a threat to any species [3]; $\mathrm{CaCO}_{3}$-based materials can in fact be employed for removal of both heavy metals or organic pollutants [4,5]. For this purpose, $\mathrm{CaCO}_{3}$ can also be used in a composite with other materials [6-9].

In addition to this, $\mathrm{CaCO}_{3}$ is also one of the possible calcium sources in the preparation of calcium phosphate materials such as hydroxyapatite $[10,11]$, widely used for both environment remediation and bone replacement. In comparison with other calcium sources, the use of carbonate has the advantage that it is possible to obtain carbonated hydroxyapatite, which resembles more closely the composition of human bone and, therefore, shows improved biocompatibility [12].

Porosity, morphology and surface area are key issues, which can affect the properties of materials; indeed, the literature reported examples of enhanced pollutants removal achieved by highly porous $\mathrm{CaCO}_{3}$ [2]. $\mathrm{CaCO}_{3}$ exhibiting hierarchical porosity - pores with dimensions in distinct ranges, such as micro and nanoscale - showed enhanced functional properties [13,14].

Natural template agents can be employed to prepare materials with an ordered structure as well as tailored porosity; wood-derived ceramics, in particular, have received increasing interest due to the interesting properties of the prepared ceramics [15]. If the natural template source is sustainable, these are also known as ecoceramics (environmentally conscious ceramics) [16]. Despite the potential of woodbased template agents, however, the majority of studies were

\footnotetext{
* Corresponding author.

E-mail address: clara.piccirillo@nanotec.cnr.it (C. Piccirillo).
} 
performed on SiC-based ceramics [15]. Regarding $\mathrm{CaCO}_{3}$ materials, very few investigations have been reported in the literature $[17,18]$.

Considering different types of wood, cork is a material with particularly interesting structure and properties. Cork is the bark of the oak tree Quercus suber L. and its main components are suberin (about $45 \%$ ) and lignins (about $22 \%$ ). At a microstructural level, it is formed of cells in a hexagonal honeycomb shape in the radial direction, and rectangular in the transverse directions, with average dimensions of about $15-20 \mu \mathrm{m}$ and $40-45 \mu \mathrm{m}$, respectively. The thickness of the walls of the cells is 1-1.5 $\mu \mathrm{m}$; moreover, they are crossed by channels with a $100 \mathrm{~nm}$ diameter [19]. Due to this microstructure, cork-derived materials are very porous and show high surface area. In addition to these advantages, it must be remembered that cork is also sustainable, as the bark is harvested every 9-13 years without harming the tree, which lives on as a carbon sink with a productive life of around 200 years [20]. As such, cork is a truly sustainable source, and optimal to be employed as a biomimetic natural template for the growth of porous materials.

Some investigations were recently performed on the preparation of cork-derived ecoceramics; indeed, various biomorphic ceramics including ferrites, silicon carbide, ceria $\left(\mathrm{CeO}_{2}\right)$ and zinc oxide were prepared using cork as template agent [21-25]. These studies led to interesting results, showing the potential of cork as an effective template agent to obtain materials with high porosity and an ordered microstructure.

In this work, we report a study on the preparation of $\mathrm{CaCO}_{3}$ using cork as template, different water-solubilised calcium precursors (nitrate, acetate and lactate) as inorganic post-pyrolysis impregnating agent and different thermal treatments (air calcination or inert-atmosphere pyrolysis). The cork used in this work was a waste cork powder, adding an additional factor of sustainability in the valorisation of this sustainable template; such powder was pyrolysed, to convert it into graphitic carbon, and successively infiltrated with the calcium precursors. Samples were characterised with various techniques, to determine their phase composition, morphology and macro/microporosity features.

\section{Experimental section}

\subsection{Pyrolysis of the cork powder}

Cork waste powder was supplied by Amorim Cork Composite (Mozelos, PT). The average dimension of the particle size was in the range $200-400 \mu \mathrm{m}$; the cork had previously been treated in hot water $\left(100{ }^{\circ} \mathrm{C}\right)$, a standard industrial process aimed at obtaining a uniform and regular structure.

The cork powder, placed in graphite crucibles, was initially pyrolysed using a Nabertherm RHTH 120-600/16 horizontally-designed high-temperature tube furnace. Prior to the pyrolysis, high vacuum conditions were realised via turbomolecular pump; successively, the pressure was raised to standard atmospheric conditions through a flow of oxygen-free nitrogen. Inert gas flow was maintained during the whole pyrolysis process. The heating sequence of pyrolysis was as follows: $i$ ) a heating ramp from room temperature to $700^{\circ} \mathrm{C}$ at a rate of $5{ }^{\circ} \mathrm{C} / \mathrm{min}$; ii) heating ramp from $700^{\circ} \mathrm{C}$ to $900^{\circ} \mathrm{C}$ at a rate of $1{ }^{\circ} \mathrm{C} / \mathrm{min}$; and then iii) $30 \mathrm{~min}$ dwell at $900^{\circ} \mathrm{C}$. The furnace was successively naturally cooled down at room temperature. The as-obtained pyrolysed cork was entirely black in colour. These conditions were chosen considering previous work performed on the pyrolysation of cork [25]; indeed previous experiments showed that a full graphitisation only takes place for $\mathrm{T}>700{ }^{\circ} \mathrm{C}$. Moreover, the use of a different inert gas (i.e. argon) led to a material with the same features.

\subsection{Chemical conversion of the cork powder into calcium carbonate/oxide}

To convert the pyrolysed cork powder into calcium carbonate, a
Table 1

Sample prepared as preliminary experiments to test the infiltration and the thermal treatment conditions. In all these tests, the ratio $\mathrm{Ca}: \mathrm{C}$ (calcium to carbon from pyrolysed cork, in moles) was $1: 1$, the heating ramp was $1{ }^{\circ} \mathrm{C} / \mathrm{min}$ up to $700{ }^{\circ} \mathrm{C}$, dwell time was $30 \mathrm{~min}$ at $700{ }^{\circ} \mathrm{C}$. Three cycles of infiltration were performed before heat treatment.

\begin{tabular}{lll}
\hline Sample name & Precursor & Thermal treatment \\
\hline CaNit_Cal & $\mathrm{Ca}\left(\mathrm{NO}_{3}\right)_{2}$ & calcination \\
CaNit_Pyr & $\mathrm{Ca}\left(\mathrm{NO}_{3}\right)_{2}$ & pyrolysis \\
CaAc_Cal & $\mathrm{Ca}\left(\mathrm{CO}_{2} \mathrm{CH}_{3}\right)_{2}$ & calcination \\
CaAc_Pyr & $\mathrm{Ca}\left(\mathrm{CO}_{2} \mathrm{CH}_{3}\right)_{2}$ & pyrolysis \\
\hline
\end{tabular}

Note: in the sample name, Nit corresponds to calcium nitrate, Ac to calcium acetate, Cal to a calcination treatment while Pyr to a pyrolysis.

Table 2

List of samples prepared through infiltration using calcium acetate or lactate precursors, followed by pyrolysis (heating in an inert atmosphere). Ca: $\mathrm{C}$ ratio is that of calcium to carbon from pyrolysed cork, in moles. In all these tests, three cycles of infiltration were performed prior to heating.

\begin{tabular}{lllll}
\hline $\begin{array}{l}\text { Sample } \\
\text { name }\end{array}$ & Precursor & Ca:C ratio & Temperature $\left({ }^{\circ} \mathrm{C}\right)$ & $\begin{array}{l}\text { Dwell time } \\
\text { (min) }\end{array}$ \\
\hline CaAc_1 & $\mathrm{Ca}\left(\mathrm{CO}_{2} \mathrm{CH}_{3}\right)_{2}$ & $1: 3$ & 500 & 30 \\
CaAc_2 & $\mathrm{Ca}\left(\mathrm{CO}_{2} \mathrm{CH}_{3}\right)_{2}$ & $1: 3$ & 700 & 30 \\
CaAc_3 & $\mathrm{Ca}\left(\mathrm{CO}_{2} \mathrm{CH}_{3}\right)_{2}$ & $1: 6$ & 700 & 30 \\
CaAc_4 & $\mathrm{Ca}\left(\mathrm{CO}_{2} \mathrm{CH}_{3}\right)_{2}$ & $1: 6$ & 700 & 240 \\
CaLac_1 & $\mathrm{Ca}\left(\mathrm{CO}_{2} \mathrm{CHOHCH}_{3}\right)_{2}$ & $1: 3$ & 700 & 30 \\
CaLac_2 & $\mathrm{Ca}\left(\mathrm{CO}_{2} \mathrm{CHOHCH}_{3}\right)_{2}$ & $1: 6$ & 500 & 30 \\
CaLac_3 & $\mathrm{Ca}\left(\mathrm{CO}_{2} \mathrm{CHOHCH}_{3}\right)_{2}$ & $1: 6$ & 700 & 30 \\
CaLac_4 & $\mathrm{Ca}\left(\mathrm{CO}_{2} \mathrm{CHOHCH}_{3}\right)_{2}$ & $1: 6$ & 700 & 240 \\
\hline
\end{tabular}

strategy of impregnation with different calcium salts was realised. Briefly, $25 \mathrm{mg}$ of cork powder were dispersed into an aqueous solution of a calcium-based salt (either nitrate, acetate or lactate), and afterwards the solvent was removed under vacuum conditions with a waterbath rotary evaporator; the evaporation was performed at $80^{\circ} \mathrm{C}$.

As reported in Tables 1 and 2, different $\mathrm{Ca}: \mathrm{C}$ molar ratios were tested, by assuming the pyrolysed cork powder to be pure carbon; the calcium solution volume used was always $15 \mathrm{ml}$. Thereafter, the powder was dried at $45-60^{\circ} \mathrm{C}$ overnight, and successively either calcined in air or pyrolysed, as listed in Tables 1 and 2 . In all cases the heating ramp was $1^{\circ} \mathrm{C} / \mathrm{min}$.

For selected samples, the $\mathrm{W}_{\mathrm{G}}$ weight gain percentage after the infiltration and the pyrolysis stages was calculated according to the formula:

$W_{G}=\frac{W_{f}-W_{i}}{W_{i}} x 100$

where $\mathrm{W}_{\mathrm{i}}$ is the initial weight of the pyrolysed cork powder and $\mathrm{W}_{\mathrm{f}}$ is the final weight of the powder, either after the infiltration or after the infiltration followed by the thermal treatment.

\subsection{Characterisation}

Phase composition of the samples was determined through X-ray diffraction (XRD), using a Rigaku Geigerflex D/max C-series, with Cu K$\alpha$ radiation. The diffraction patterns were acquired at a speed of $3^{\circ} \%$ min, with a step $0.02^{\circ}$, between 5 and $80^{\circ}$. Crystalline phases were identified using the JCPDF standard files 00-019-0199 $\left(\mathrm{CaC}_{4} \mathrm{H}_{6} \mathrm{O}_{2} \times 0.5 \mathrm{H}_{2} \mathrm{O}\right), 00-005-0586\left(\mathrm{CaCO}_{3}\right.$, calcite), 00-37-1497 (CaO) and 01-073-5492 $\left(\mathrm{Ca}(\mathrm{OH})_{2}\right)[26,27]$. Crystallite size were calculated using the Schrerrer equation, considering the (104) calcite peak, for $2 \theta=29.41^{\circ}$.

Raman spectra were taken with a Horiba MicroRaman Xplora (laser at $532 \mathrm{~nm}$, power $0.125 \mathrm{~mW} \mathrm{~cm}^{-2}$ ), while a JASCO-6300 spectrometer was used for the FTIR measurements. Thermogravimetric and 
differential thermal analysis (TGA/DTA) were performed using SDT Q600 equipment (TA Instruments), with a nitrogen flow rate of $100 \mathrm{ml} /$ min and a heat ramp of $5{ }^{\circ} \mathrm{C} / \mathrm{min}$.

The powders' morphology was studied using scanning electron microscopy (SEM, Hitachi S-4100) with $25 \mathrm{kV}$ voltage. Prior to the analysis, samples were coated with gold. The surface area of each sample was measured by a Micrometrics Gemini VII Surface Area Analyzer (Micrometrics Instruments Corp., Norcross, GA, USA), using $\mathrm{N}_{2}$ as adsorbate and outgassing the samples at $120^{\circ} \mathrm{C}$. The adsorption/desorption isotherms were measured, and the specific surface area (SSA) was determined according to the BET method.

\section{Results and discussion}

\subsection{Preliminary tests}

Some preliminary infiltration experiments were performed using an aqueous solution of calcium acetate or calcium nitrate, with a Ca:C molar ratio of 1:1. The infiltrations were performed by evaporating the water under vacuum. Previous studies had already shown the effectiveness of the infiltration action, using this protocol [21,25]. Reasonably, high vacuum conditions ensure the effective removal of air entrapped in the pyrolysed powder, promoting the infiltration of the solution into both the microsized pores of the cells and nanosized ones of the cell walls. Three infiltration cycles were performed, to ensure a significant weight gain [24]. Finally, as summarized in Table 1, each sample was alternately exposed to further thermal treatment, that is calcination in air or a nitrogen atmosphere-based pyrolysis, both at $700{ }^{\circ} \mathrm{C}$. These two gases were chosen as they could lead to different reactions paths, between calcium, carbon originating from the pyrolysed cork and the inorganic residue of the precursor salts, essentially directed by a mass effect. No carbon-containing gas (i.e. $\mathrm{CO}_{2}$ ) was used for the thermal treatment; this was done to assess whether the calcium carbonate could be formed from just the residual carbon from the precursor salts and/or the pyrolysed cork, without any additional gaseous carbon source.

In Fig. 1(a-e) the XRD patterns and SEM micrographs of calcium acetate-processed materials are reported. XRD data show that different phases were formed according to the gas employed; air (CaAc_cal, line A), in fact, promotes the formation of $\mathrm{CaCO}_{3}$ (calcite), which is the main component, with $\mathrm{Ca}(\mathrm{OH})_{2}$ as a secondary phase. These results indicate that the calcium from the acetate tends to react with the carbon present in the system - in this case, the carbon sources are both the pyrolysed cork and the acetate counter-ion. The $\mathrm{CaCO}_{3}$ formed here is reasonably crystalline; the reaction with the oxygen from the air also takes place, but to a lesser extent, and forms $\mathrm{Ca}(\mathrm{OH})_{2}$.

When inert pyrolysis is performed (CaAc_pyr, line $\mathrm{B}$ ), on the other hand, the only phase detected is $\mathrm{CaCO}_{3}$. This indicates that only the reaction with carbon takes place, with no direct reaction between oxygen and calcium. The $\mathrm{CaCO}_{3}$ produced was more crystalline than that observed for CaAc_cal. SEM images of CaAc_cal show that under calcination the cork morphology is completely lost (Fig. 1(b)).

The needles/plates, typical of $\mathrm{Ca}(\mathrm{OH})_{2}$ formation, are not observed; indeed the XRD indicated that this sample proportionately does not contain large amount of $\mathrm{Ca}(\mathrm{OH})_{2}$. At higher magnification, more regular morphologies made by larger (about $500-700 \mathrm{~nm}$ ) polyhedral crystals of monodisperse size can be observed (Fig. 1(c)). This explains the relatively high degree of crystallinity for the $\mathrm{CaCO}_{3}$ phase. For CaAc_pyr (Fig. 1(d-e)), on the contrary, some residual cork structure can be observed; in fact, some cells of about $20 \mu \mathrm{m}$ diameter are present, with thin cell walls. This can be seen more clearly in the micrograph with higher magnification (Fig. 1(e)). Fig. 1(d), however, also shows that in some areas the cells' structure is not maintained.

XRD analysis and SEM investigations of samples obtained by cork impregnation with calcium nitrate are reported in Fig. S1 (a-e). This system exhibits the lowest-grade features, both in terms of composition
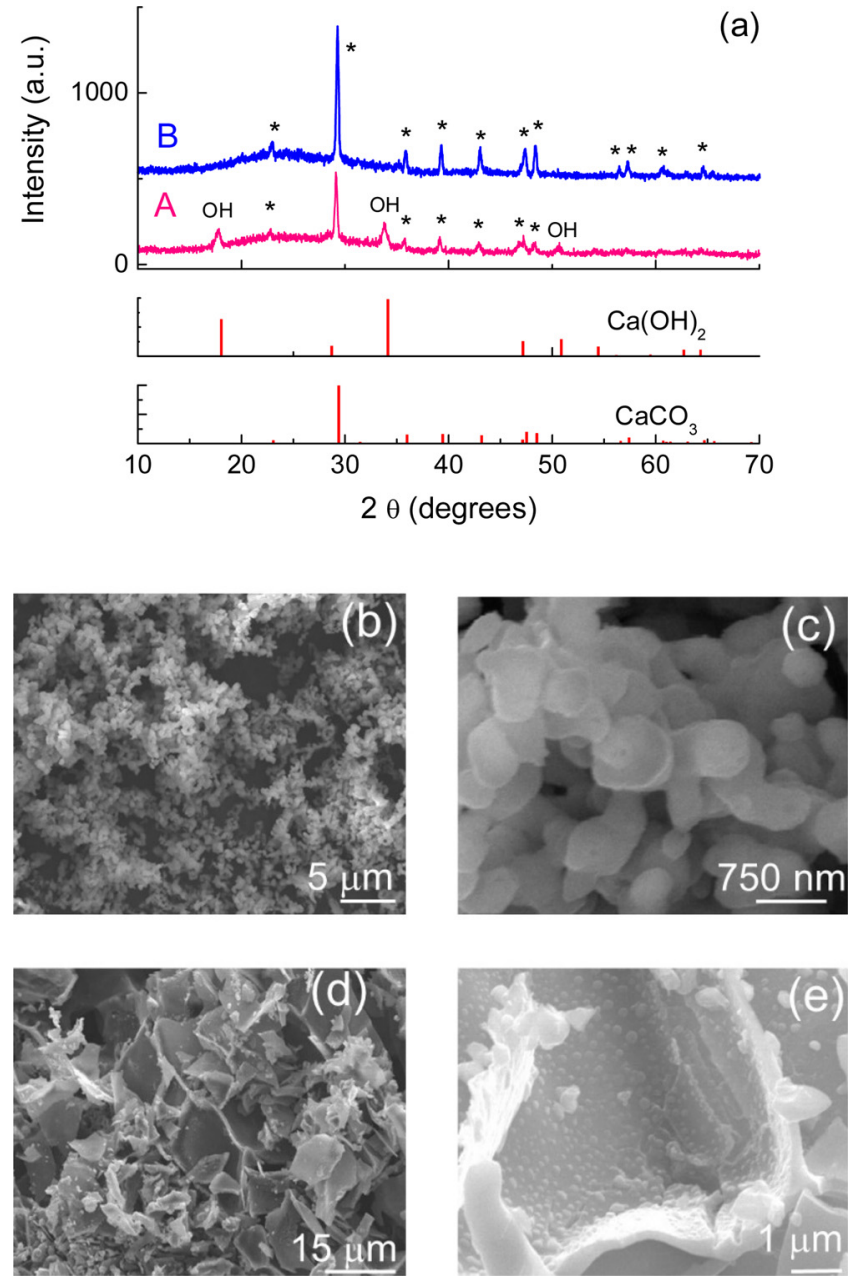

Fig. 1. (a) XRD patterns for samples prepared from calcium acetate. A: CaAc_cal; B: CaAc_pyr; (b-c) SEM micrographs for sample CaAc_cal; (d-e) SEM micrographs for sample CaAc_pyr. All samples heated to $700^{\circ} \mathrm{C}$. In the $\mathrm{XRD}$ patterns the peaks marked with an asterisk (*) belong to $\mathrm{CaCO}_{3}$.

and morphology. Regarding the composition, XRD patterns show that the calcination treatment (CaNit_cal, line A) led to a sample with low crystallinity, and consisting of a mixture of $\mathrm{Ca}(\mathrm{OH})_{2}$ and $\mathrm{CaCO}_{3}$. The inert atmosphere (line $\mathrm{B}$ ), on the other hand, promoted $\mathrm{CaCO}_{3}$ as the main phase composition although traces of $\mathrm{CaO}$ were also detected.

The micrographs of these samples show that both thermal treatments led to a complete loss of the original cell-like cork structure (see Fig. S1(b, d) for CaNit_cal and CaNit_pyr, respectively); images at higher magnification (Fig. S1(c, e)) establish the irregular structure at the microscale level.

These results showing the differences of samples prepared with different salts are in good agreement with previous work carried out on zinc precursors [24], that showed the effect of counter ions on the infiltration, and on the final crystalline structure. The experiments with zinc-based compounds also showed the loss of the cork structure caused by thermal treatment, primarily attributable to the released latent heat, which led to complete combustion and/or damage of the cells' walls. Nitrates are known to undergo strongly exothermic decomposition at relatively low temperatures [28]. Furthermore, in this case, comparing the nitrate and acetate systems, the nitrate solution showed a much greater viscosity; this may have restricted its degree of infiltration, and affected the reactions occurring on the surface of the pyrolysed powder and the microstructure of the powders as a result.

In view of the multiphase composition-growing samples and poor cork-like morphology, the experimental route related to calcium nitrate 

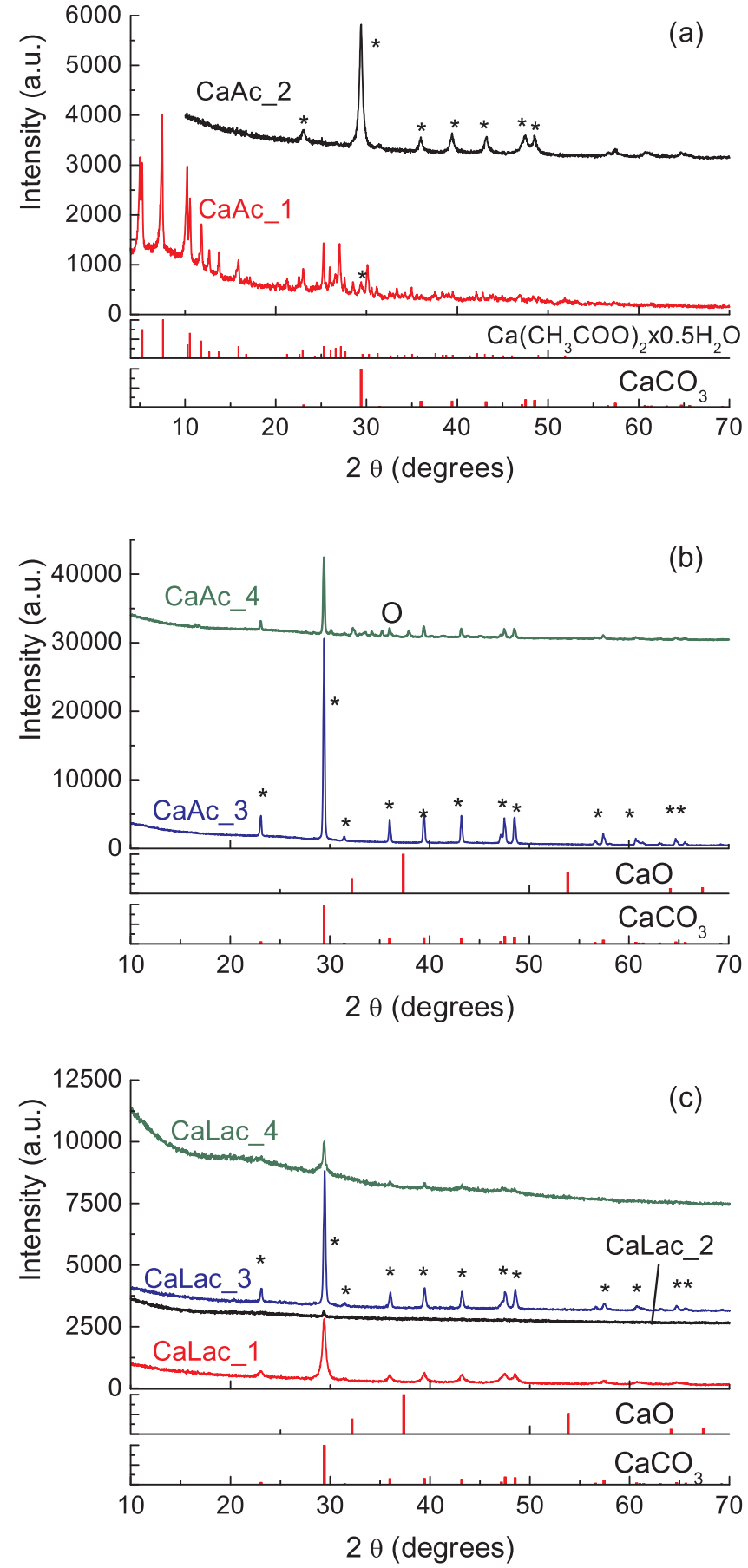

Fig. 2. XRD patterns for the samples (a) CaAc_1 and CaAc_2; (b) CaAc_3 and CaAc_4; (c) CaLac_1, CaLac_2, CaLac_3 and CaLac_4. Peaks marked with an asterisk belong to $\mathrm{CaCO}_{3}$.

impregnation was not further investigated. The work was, therefore, primarily focused on the use of calcium acetate as the impregnation precursor, subsequently annealed under an inert atmosphere. To achieve a more complete preservation of the cork-like porous structure, infiltrations were performed using smaller quantities of calcium precursor, with Ca:C ratios of 1:3 and 1:6 (see Table 2). Moreover, some additional experiments were also performed using calcium lactate as a precursor, considering that the molecular structure of the organic lactate anion $\left(\mathrm{CH}_{3} \mathrm{CH}(\mathrm{OH}) \mathrm{COO}^{-}\right)$is similar to that of acetate $\left(\mathrm{CH}_{3} \mathrm{COO}^{-}\right)$, with the sole exception of an extra $\mathrm{CH}(\mathrm{OH})$ group.
Table 3

Average crystallite size for the $\mathrm{CaCO}_{3}$ samples, calculated using the Scherrer equation.

\begin{tabular}{ll}
\hline Sample name & Crystallite size (nm) \\
\hline CaAc_1 & - \\
CaAc_2 & 16.59 \\
CaAc_3 & 46.93 \\
CaAc_4 & 63.18 \\
CaLac_1 & 16.66 \\
CaLac_2 & - \\
CaLac_3 & 34.95 \\
CaLac_4 & 21.33 \\
\hline
\end{tabular}

Note. For each value the error is lower than $2 \%$.

\section{2. $\mathrm{CaCO}_{3}$ samples made from acetate and lactate}

The full list of samples prepared from either calcium acetate or lactate is given in Table 2; it can be seen that two different temperatures (500 and $700{ }^{\circ} \mathrm{C}$ ) were considered, to assess the most suitable conditions to prepare $\mathrm{CaCO}_{3}$, whilst maintaining the porous cork structure.

Fig. 2 shows the XRD patterns for these samples, while Table 3 reports the values of the crystallite size calculated from these patterns. Considering the materials prepared from calcium acetate (Fig. 2(a)), it can be noted that the powder pyrolysed at $500{ }^{\circ} \mathrm{C}$ (CaAc_1) shows the pattern corresponding to partially hydrated calcium acetate $\mathrm{Ca}$ $\left(\mathrm{CH}_{3} \mathrm{CO}_{2}\right)_{2} \cdot 0.5 \mathrm{H}_{2} \mathrm{O}$ [29]; this compound could be formed either from the partial dehydration of the $\mathrm{Ca}\left(\mathrm{CH}_{3} \mathrm{CO}_{2}\right)_{2} \cdot 2 \mathrm{H}_{2} \mathrm{O}$ employed in the infiltrations, or through the interaction of the dried infiltrated salt with the residual water incorporated in powder.

The formation of this compound was previously observed [29]; nevertheless, as opposed to our results, the literature showed this to be effectively degraded at $\mathrm{T}<150^{\circ} \mathrm{C}$. It is worth remembering that, in our case, the high-temperature nitrogen-based decomposition of calcium acetate is not performed on the pure salt, but in the presence of pyrolysed cork. Our data seem to show that the interaction between the cork-derived graphite and the infiltrated calcium acetate made the acetate salt more stable, i.e. requiring a higher temperature to be degraded.

The XRD pattern of CaAc_1 also shows traces of $\mathrm{CaCO}_{3}$. These data indicate that with the pyrolysis of the infiltrated powder at $500{ }^{\circ} \mathrm{C}$, a very small degree of conversion of the precursor into $\mathrm{CaCO}_{3}$ takes place.

At higher pyrolysis temperatures, on the other hand, a full conversion can be achieved; CaAc_2, pyrolysed at $700{ }^{\circ} \mathrm{C}$, shows only the $\mathrm{CaCO}_{3}$ diffraction pattern, in agreement with that observed in Fig. 1(a). An even lower Ca:C molar ratio (1:6, CaAc_3; Fig. 2(b)) promotes a more crystalline material in which the peaks are sharper and more intense; the higher crystallinity is confirmed also by the higher value of the crystallite size - 46.93 vs. $16.59 \mathrm{~nm}$ for samples CaAc_3 and CaAc_2, respectively. Using the same stoichiometric ratio, but a longer pyrolysis time of $240 \mathrm{~min}$ (CaAc_4) causes a further increase in the crystallinity of the powder (crystallite size of $63.18 \mathrm{~nm}$ ); however, traces of other phases such as $\mathrm{CaO}$ can also be observed. This indicates that a $30 \mathrm{~min}$ pyrolysis period at $700{ }^{\circ} \mathrm{C}$ is the most desirable option.

For the materials prepared from lactate (Fig. 2(c)), only a very weak peak of $\mathrm{CaCO}_{3}$ is present in the pattern of the sample pyrolysed at $500{ }^{\circ} \mathrm{C}$ (CaLac_2); this is in agreement with that observed for the sample made from calcium acetate (CaAc_1), which also contained very little $\mathrm{CaCO}_{3}$. The main difference here is that no other phase can be detected; this indicates that, at this temperature, calcium lactate was completely degraded (unlike calcium acetate at $500{ }^{\circ} \mathrm{C}$ ), but without forming any other crystalline compounds. For all the lactate samples treated at $700{ }^{\circ} \mathrm{C}$, on the other hand, a very clear $\mathrm{CaCO}_{3}$ diffraction pattern is present, similar to that observed for the samples prepared from calcium acetate at this temperature; the powder with the higher crystallinity is CaLac_3 (see Table 3 for the crystallite size). The high-temperature 

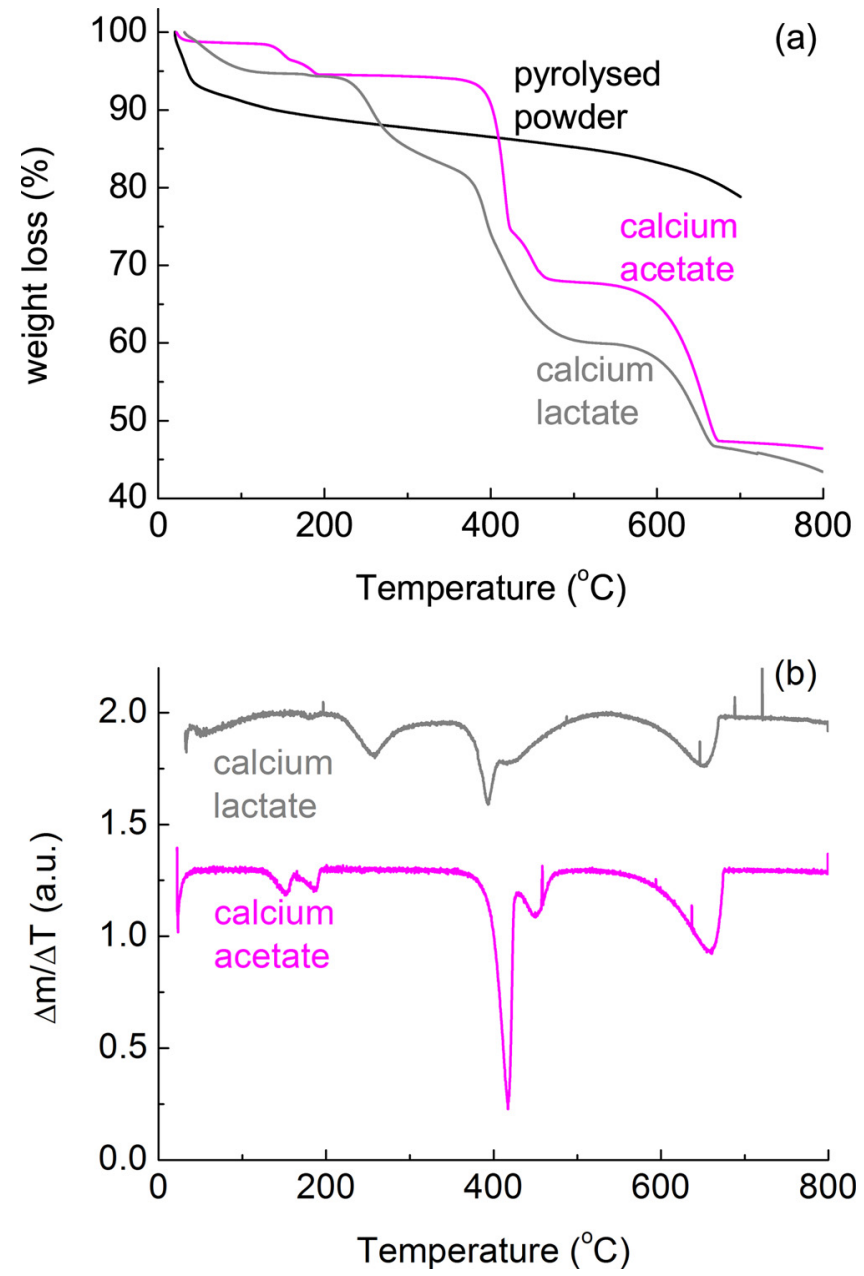

Fig. 3. TGA data. (a) Comparison between the pyrolysis of the non-infiltrated powder and the powders infiltrated with either acetate or lactate. (b) First derivative of the curves of the two infiltrated powders.

process of pyrolysis extended for long-time periods $\left(700^{\circ} \mathrm{C} / 240 \mathrm{~min}\right)$, led to a decrease in the crystallite size (from about 34 to $21 \mathrm{~nm}$ ), unlikeacetate-based samples. Overall, data from Table 3 showed that the use of calcium lactate as precursor corresponded to lower crystallinity. No other phases were detected in any of the samples.

\subsection{TGA analysis}

To better understand the processes taking place during the pyrolysis of the infiltrated powders, and correlate this with the composition of the materials shown by the XRD data, TGA measurements were carried out, thoroughly reproducing the oxygen-free pyrolysis conditions. Results are shown in Fig. 3.

Fig. 3(a) reports the percentage weight loss as a function of the temperature, the graph showing the curves for the simple pyrolysed cork powder and for both organic salt infiltrated powders (Ca:C ratio $1: 6)$. As expected, a relatively small change in weight $(\sim 20 \%)$ is observed for the non-infiltrated pyrolysed cork powder under pyrolysis up to $700{ }^{\circ} \mathrm{C}$ - this matches previously reported results for pyrolysed cork [25]. On the other hand, for both the infiltrated powders, several weight losses at different temperature intervals can be observed.

This confirms that various reactions take place, leading to the formation of different phases. Comparing the curves for the two precursors, they have some common characteristics, but also some differences. The overall weight loss, for instance, is comparable for the two systems, i.e. about $45 \%$; this indicates that the infiltration of the calcium precursor and its conversion to carbonate is comparable for the two systems. The curves, however, show different weight losses at different temperatures. To better visualise these changes, the first derivative of the weight loss curves were considered (see Fig. 3(b)).

It can be seen that for both acetate and lactate infiltrated powders, a significant peak is present for $\mathrm{T}>500{ }^{\circ} \mathrm{C}$; considering the results of the XRD measurements, it can be deduced that this peak corresponds to the formation of calcium carbonate, through the reaction of the calcium with the organic fragments derived from the precursors and present in the system. The peaks observed at lower temperatures, on the other hand, belong to the changes taking place in the infiltrated powders prior to carbonate formation; they are correlated to the chemical structure of the precursors and, therefore, they are different for the two materials.

As shown in Fig. 2(c), CaLac_2 (powder pyrolysed at $500^{\circ} \mathrm{C}$ ) did not show any residues of the lactate precursor; this indicates that the peaks detected for temperatures lower than $500^{\circ} \mathrm{C}$ are associated with the degradation of the lactate itself. Considering the curve in Fig. 3(b), a small peak is present at about $50^{\circ} \mathrm{C}$, which corresponds to the desorption of the water molecules adsorbed on the surface of the powder. Two stronger peaks can be detected for $230<\mathrm{T}<350{ }^{\circ} \mathrm{C}$ and for $350<\mathrm{T}<500^{\circ} \mathrm{C}$; the latter one, in particular, is composed of two signals, a sharp one just below $400{ }^{\circ} \mathrm{C}$ and a wider one just above it. These peaks can be associated with the decomposition of the lactate ion, which takes place in successive steps; indeed, the various functional groups present in the anion may need different amounts of energy (and hence temperature) to be degraded. The possible interactions of the functional groups with the carbon of the pyrolysed powder can also play a role in their degradation and the associated weight loss. Overall, the pyrolysis of the lactate-infiltrated powder for temperatures up to $500{ }^{\circ} \mathrm{C}$ leads to a graphitic material containing the calcium ion and some residual organic carbon, as well as oxygen, not organised in a crystalline form and, hence, not detectable by XRD, which successively led to the formation of $\mathrm{CaCO}_{3}$ (at $\mathrm{T}>500{ }^{\circ} \mathrm{C}$ ).

Considering the acetate-infiltrated powder, as stated already above, XRD data showed the presence of the hydrated calcium acetate for the sample pyrolysed at $500{ }^{\circ} \mathrm{C}$ (CaAc_1). Based on this, it may seem that not many significant structural changes take place in the calcium acetate-infiltrated powder between room temperature and $500^{\circ} \mathrm{C}$, i.e. just a slight interaction with water molecules. TGA data, however, show the opposite: a significant weight loss $(>30 \%)$ is registered, taking place over 4 separate steps - the first two for $\mathrm{T}<200^{\circ} \mathrm{C}$ and the following two for $350<\mathrm{T}<500^{\circ} \mathrm{C}$ (Fig. 3(b)). These peaks correspond to the thermal degradation of the different groups of the acetate ion; although there are some similarities, the temperatures at which such processes take place are different from those observed for the lactate. This is reasonable since the two anions are constituted of different functional groups.

The fact that XRD data at $500{ }^{\circ} \mathrm{C}$ still show the presence of Ca $\left(\mathrm{CH}_{3} \mathrm{CO}_{2}\right)_{2} \cdot 0.5 \mathrm{H}_{2} \mathrm{O}$ indicates that a significant amount of the residual precursor persists. Our hypothesis is that the calcium acetate present on the surface of the cork cells is degraded, while a significant portion, infiltrated into the $100 \mathrm{~nm}$ small channels within the walls of the cork cells, remains stable at $500{ }^{\circ} \mathrm{C}$ because of the interactions with the carbon of the cells. For $\mathrm{T}>500{ }^{\circ} \mathrm{C}$, complete conversion into $\mathrm{CaCO}_{3}$ is observed, and the weight loss associated with this final step is greater than for the lactate (25 vs. $15 \%$, respectively). Despite this, the final overall weight loss at $700{ }^{\circ} \mathrm{C}$ is almost identical for both acetate and lactate salts.

\subsection{Morphology of the samples}

Figs. 4 and 5 report the SEM images for the samples prepared from calcium acetate and lactate, respectively. Considering the calcium acetate-derived powders, micrographs show that with $\mathrm{Ca}: \mathrm{C}$ ratio $1: 3$ the cork structure is maintained with pyrolysis at both 500 and $700{ }^{\circ} \mathrm{C}$ 

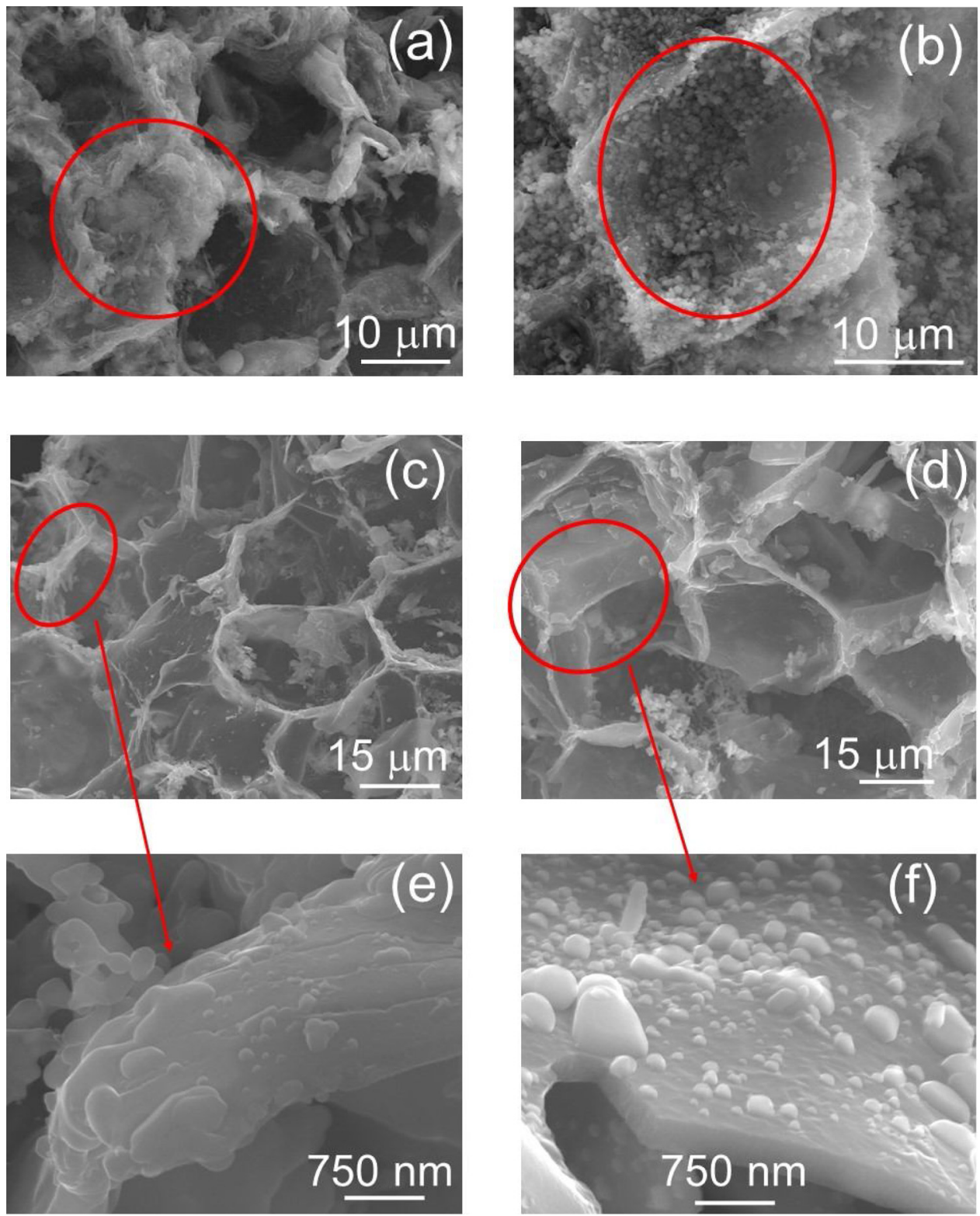

Fig. 4. SEM micrographs for samples prepared from calcium acetate; (a) CaAc_1; (b) CaAc_2; (c) and (e): CaAc_3; (d) and (f): CaAc_4.

(CaAc_1 and CaAc_2, Fig. 4(a) and (b), respectively). In some areas, however, the cells are completely filled (see the marked area in Fig. 5(a)); also, Fig. 4(b) shows the presence of rounded crystallites in the rear walls of the cells. The $\mathrm{CaCO}_{3}$ yield for CaAc_2 is about $69 \%$. By reducing the $\mathrm{Ca}: \mathrm{C}$ ratio (1:6, CaAc_3, Fig. 4(c)), a lower yield is obtained (about $43 \%$ ); the cork structure, however, is better preserved and the cells appear more regular. A micrograph at higher magnification (Fig. 4(e)) shows the growth of small crystals on the wall of the cells. The increase of the pyrolysis time to $4 \mathrm{~h}$ (CaAc_4, Fig. 4(d)) leads to partial damage/loss of the cork structure, caused by the additional heat released during the time-expanded pyrolysis. This effect is even more enhanced for the longer pyrolysis time, as demonstrated for CaLac_4, pyrolysed for $4 \mathrm{~h}$, which shows that the cork structure was not preserved (Fig. 5(d)).

It is also likely that, with longer pyrolysis time, more cork-derived carbon reacts with the infiltrated salt to make carbonate; this may lead to a partial damage of the cork 3D structure. Fig. 4(f) highlights the presence of crystals of irregular size on the wall of the cells.

For the samples prepared with calcium lactate, the use of $\mathrm{Ca}: \mathrm{C}$ ratio of 1:3 (Fig. 5(a), CaLac_1) led to an almost complete loss of the cell structure; it can be seen, in fact, that in some areas the walls became much thicker, while in other zones the original cell became distorted.

$\mathrm{CaCO}_{3}$ yield is $62 \%$, comparable to that observed with calcium acetate. The use of a lower Ca:C molar ratio (1:6, yield $43 \%)$ promotes more regular structures in the case of pyrolysis temperatures of $500{ }^{\circ} \mathrm{C}$ (CaLac_2, Fig. 5(b)) and a partial loss of the cells' structure at $700{ }^{\circ} \mathrm{C}$ (CaLac_3, Fig. 5(c)).

\subsection{Samples CaAc_3 and CaLac_3: further characterization}

Both XRD and SEM results indicate that the infiltration with 1:6 $\mathrm{Ca}: \mathrm{C}$ ratio, followed by pyrolysis at $700{ }^{\circ} \mathrm{C}$ for $30 \mathrm{~min}$ are the conditions leading to materials with the best characteristics, in terms of phase composition, crystallinity and cork-like morphology.

It has to be highlighted that with this process biomorphic $\mathrm{CaCO}_{3}$ was obtained with a single step, with higher energy efficiency, in comparison with other processes reported in literature. Rattan woodderived $\mathrm{CaCO}_{3}$, for instance, was obtained with two successive steps after the wood pyrolysis - carburization followed by oxidation [18]. Carburization, in particular, takes place at high temperatures 

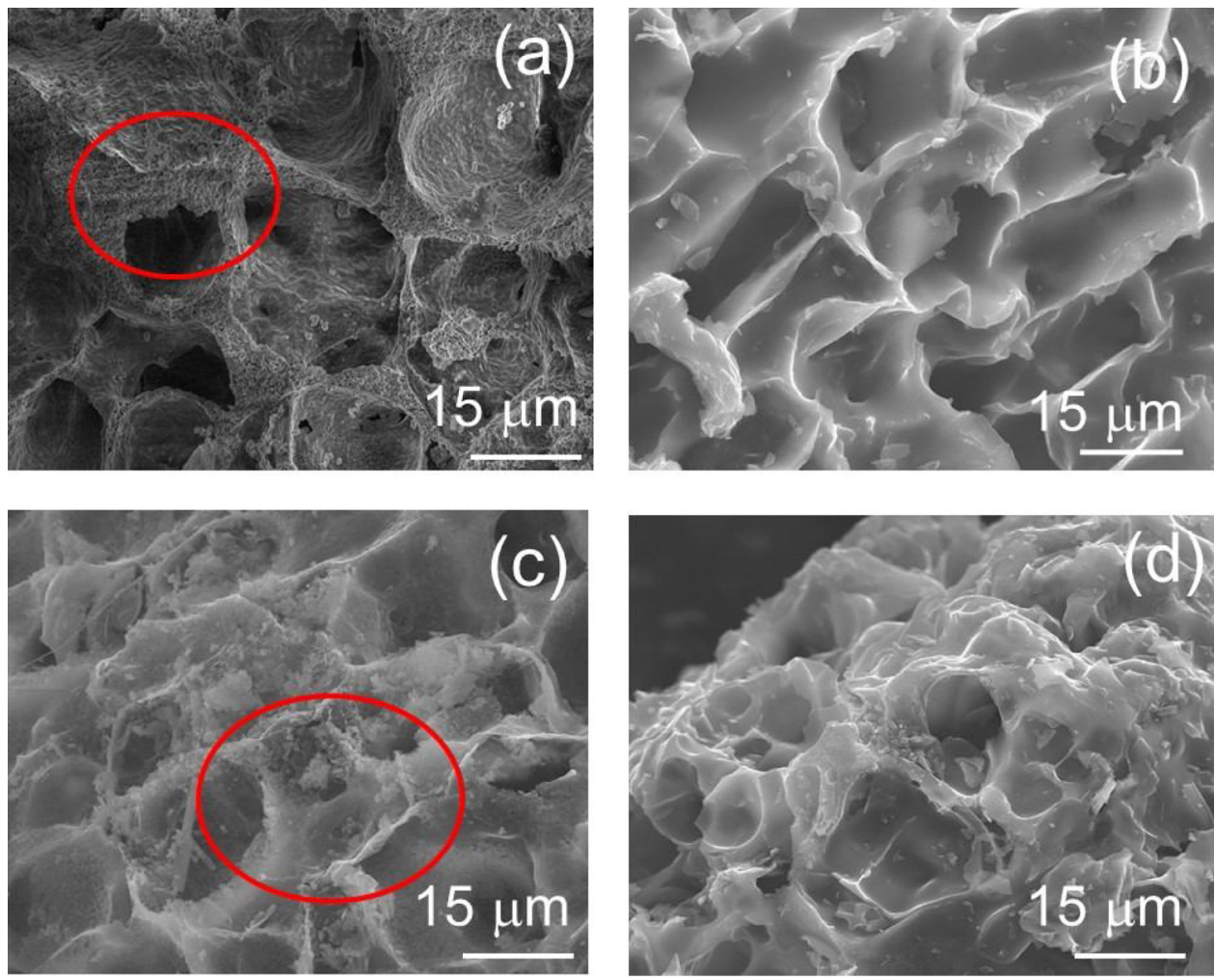

Fig. 5. SEM micrographs of the samples prepared from calcium lactate; (a) CaLac_1; (b) CaLac_2; (c) CaLac_3; (d) CaLac_4.

( $>1400{ }^{\circ} \mathrm{C}$ ), with the whole process being less sustainable. Literature reports $\mathrm{CaCO}_{3}$ obtained with natural microbial calcium carbonate precipitation techniques [30]. Such approach could reduce the energy consumption even more, and it could be considered for future work in this field.

Because of these encouraging results, additional analyses were, therefore, performed on CaAc_3 and CaLac_3.

Repeated experiments were performed, to determine the effectiveness of the infiltration process with the two precursors and of the conversion to $\mathrm{CaCO}_{3}$; results are reported in Table 4. Data show that the infiltration is much more effective when calcium acetate is used; the weight gain after the actual infiltration for the acetate is in fact more than double that measured for the lactate $(+447$ vs. $+198 \%$ respectively). Such higher infiltration rate corresponds to a greater weight gain after the pyrolysis, $+116 \%$ for the calcium acetate, while only $+33 \%$ with calcium lactate.

Although XRD analysis showed no other phase present in either of the samples, it is possible that some amorphous contamination exists, for instance some residual carbon fragments, both from the precursor(s) or from the skeleton of the pyrolysed cork. To assess this, Raman spectroscopy was employed; the spectra of samples CaAc_3 and CaLac_3 are shown in Fig. 6.

For both powders, a strong background signal can be observed; this is caused by the fluorescence of the materials, and it can be due to the

Table 4

$\mathrm{W}_{\mathrm{G}}$ and $\mathrm{CaCO}_{3}: \mathrm{C}$ ratio for selected samples.

\begin{tabular}{llll}
\hline Sample & $\begin{array}{l}\mathrm{W}_{\mathrm{G}} \text { after infiltration } \\
(\%)\end{array}$ & $\begin{array}{l}\mathrm{W}_{\mathrm{G}} \text { after pyrolysis } \\
(\%)\end{array}$ & $\begin{array}{l}\mathrm{CaCO}_{3} / \mathrm{C} \text { ratio (mol/ } \\
\mathrm{mol})^{\mathrm{a}}\end{array}$ \\
\hline CaAc_3 & 447 & 116 & 0.19 \\
CaLac_3 & 198 & 33 & 0.11 \\
\hline
\end{tabular}

Note: all values have an error of about $10 \%$.

a The values of the $\mathrm{CaCO}_{3} / \mathrm{C}$ ratio should be compared to the theoretical one -0.17 . presence of organic fragments, a feature already observed for pyrolysed materials of natural origin [31]. Despite the intense background, however, some clear and distinct peaks can be identified in both samples. For CaAc_3 (Fig. 6(a)), the signal corresponding to $\mathrm{CaCO}_{3}$ is clearly visible at $1083 \mathrm{~cm}^{-1}$, in agreement with literature [32] and with XRD data. At higher wavenumbers $\left(>1100 \mathrm{~cm}^{-1}\right.$ ), several peaks can be detected. Previous studies on cork-derived pyrolysed materials showed the presence of only the characteristic graphite signals, at 1355 and $1575 \mathrm{~cm}^{-124}$ - the D and G.

In this case, however, additional peaks are present, at 1130, 1255, 1425 and $1473 \mathrm{~cm}^{-1}$; this difference could be due to the different thermal treatment (calcination vs. pyrolysis), as well as the different infiltrating salts (zinc vs. calcium).peaks.

According to literature reports, these signals can be attributed to different C-containing functional groups; the peak at $1130 \mathrm{~cm}^{-1}$, for instance, corresponds to the vibration of the $\mathrm{C}-\mathrm{C}$ bond [32]. At about $1255 \mathrm{~cm}^{-1}$, on the other hand, the deformation of the $\mathrm{OH}$ bond can be observed, while the signals at 1426 and $1473 \mathrm{~cm}^{-1}$ correspond to the $\mathrm{C}-\mathrm{O}$ and $\mathrm{C}=\mathrm{O}$ bonds, respectively $[33,34]$. The presence of these signals indicates that, although the only crystalline phase formed is $\mathrm{CaCO}_{3}$, some residual carbonaceous matter is still present, both as graphite and as organic fragments. This could be linked to the persistence of some of the precursor acetate salt up to $500{ }^{\circ} \mathrm{C}$, as observed in the XRD patterns.

Considering Ca_Lac3, it can be seen that, the fluorescence background is still present, with a relatively high intensity for wavenumber below $1300 \mathrm{~cm}^{-1}$. Despite the high background, however, the signal associated with $\mathrm{CaCO}_{3}$ is still detectable at $1083 \mathrm{~cm}^{-1}$. The presence of higher background makes less defined and visible the peaks at 1255 and $1355 \mathrm{~cm}^{-1}$; the peaks associated to the carbon-oxygen bonds (1426 and $1473 \mathrm{~cm}^{-1}$ ), on the other hand, could not be detected. These differences may indicate that the residual carbon is present more as an impurity and not in form of carbon-oxygen fragments. This could be due to a more enhanced degradation of the precursors, in agreement with XRD data, which did not show any crystalline phase in the sample treated at 

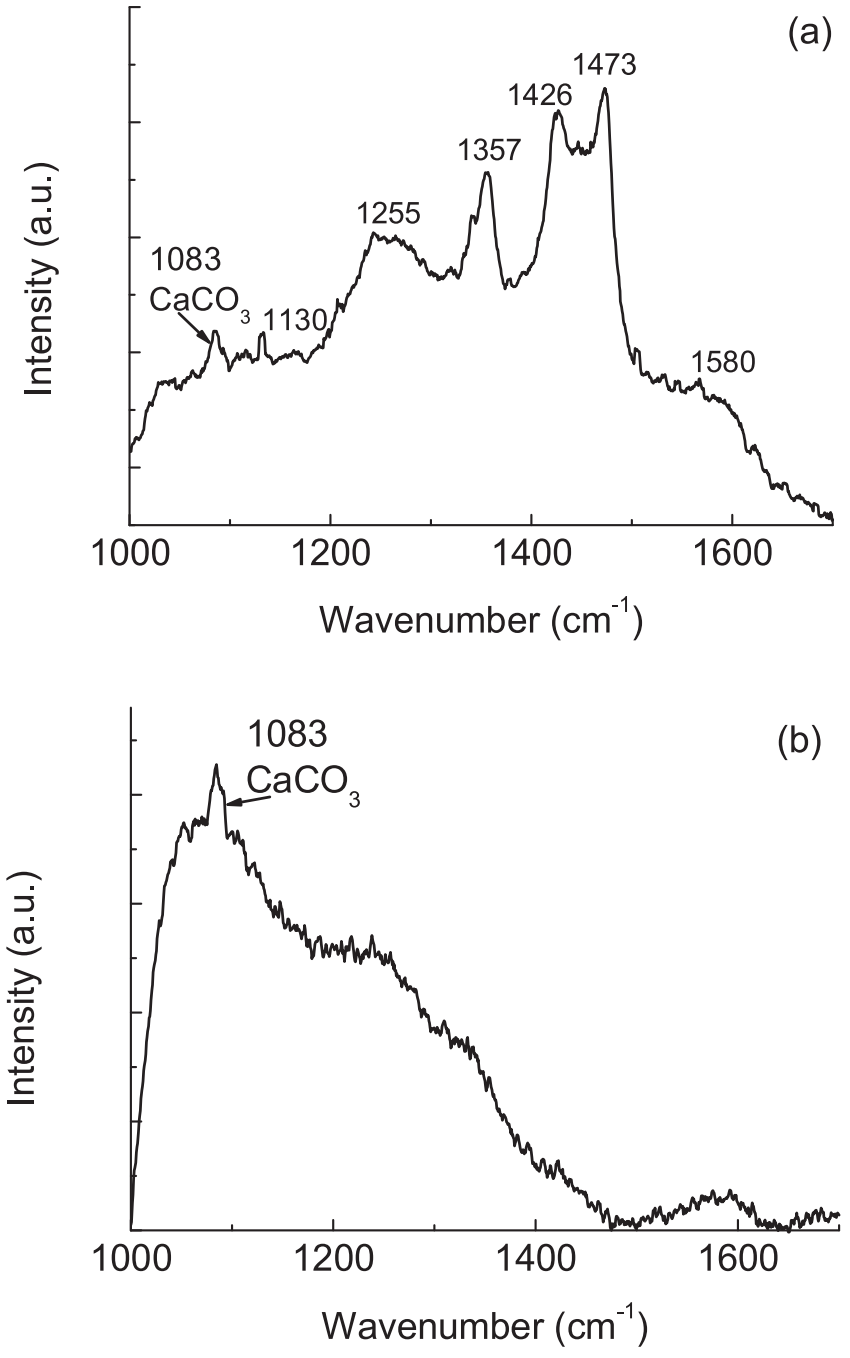

Fig. 6. Raman spectra for samples (a) CaAc_3 and (b) CaLac_3.

$500{ }^{\circ} \mathrm{C}$.

FTIR analyses were also performed, to assess whether the presence of residual carbon was just superficial, or whether some carbon was present also in the bulk of the material. Fig. S2 reports, as an example, the FTIR spectra for sample CaAc_3 as prepared, and for the same sample milled in a mortar (CaAc_3_mor); the milling treatment was performed to obtain a uniform mixing of the powder and measure not just the surface, but also the bulk of the sample. The spectrum of the pyrolysed cork is also shown as reference. FTIR was used, as with this technique the light has higher penetration into the analysed sample (up to $2 \mu \mathrm{m}$, according to the wavelength), contrary to Raman, which is a surface analysis technique.

Both spectra belonging to CaAc_3, with or without milling, are dominated by the signal arising from carbonate, and in particular of calcite [35]; they are marked with an asterisk. More specifically, at $1790 \mathrm{~cm}^{-1}$ the $\mathrm{C}=\mathrm{O}$ stretching vibration band is present; at about 1490 $\mathrm{cm}^{-1}$ a composite band arising from $\mathrm{C}-\mathrm{O}$ asymmetric stretching is well-visible; at $1080 \mathrm{~cm}-1$ a sharp peak due to $\mathrm{C}-\mathrm{O}$ symmetric stretching vibration is found; and finally, the signal localized at about $870 \mathrm{~cm}^{-1}$ is ascribable to $\mathrm{C}-\mathrm{O}$ out-of-plane bending [36]. These peaks are not detected in the spectrum of the pyrolysed cork, confirming that they belong to the $\mathrm{CaCO}_{3}$ formed with the pyrolysis process. In both spectra, however, some additional peaks are also present, due to $\mathrm{C}-\mathrm{H}$ bonds [37]. It can be seen that the two spectra are qualitatively very similar - this indicates that the residual carbon contamination is comparable on the surface and in the bulk of the sample.
As Raman and FTIR data showed residual carbon contamination, TGA measurements were performed on samples CaAc_3 and CaLac_3, to assess the amount of residual carbon left and to determine the actual quantity of $\mathrm{CaCO}_{3}$ present in each material; data can be seen in Fig. S3 (a) and (b) for the TGA curves and their derivatives respectively. It can be seen that for both samples, two main losses can be observed, for $200<\mathrm{T}<500{ }^{\circ} \mathrm{C}$, and for $500<\mathrm{T}<850^{\circ} \mathrm{C}$. Literature data indicate that $\mathrm{CaCO}_{3}$ decarboxylation $\left(\mathrm{CO}_{2}\right.$ loss to form $\left.\mathrm{CaO}\right)$ only takes place at temperatures above $500{ }^{\circ} \mathrm{C}$ [38]; therefore, the first significant weight loss measured for both samples must be due to the residual carbon present in the samples. Comparing the two samples, however, it can be seen that such weight loss is much larger for CaLac_3 than for CaAc_3 about 40 vs. $20 \%$. Considering the first derivatives of the curves (Fig. S2(b)), it can be seen that the shape of the peak corresponding to the first weight loss is quite different; in fact the peak has a broad shape for CaAc_3, while for CaLac_3 there is an overlapping of two peaks, a broader one, and a much sharper one. Such a difference in shape is likely to be due to different processes.

Comparing these data with literature, the TGA of pyrolysed cork has a very sharp peak at about $400{ }^{\circ} \mathrm{C}$, with a shape very similar to that observed to for CaLac_3; therefore, it is likely that this sample contains some unreacted carbon from the cork skeleton. This peak was not observed for $\mathrm{CaAc}_{-}$3, indicating that most of the carbon from the cork reacted to form $\mathrm{CaCO}_{3}$ in this sample. This observation is in agreement with the data of Table 4, which showed a higher weight gain for CaAc_3.

Based on the TGA data, the ratio between the formed $\mathrm{CaCO}_{3}$ and the carbon present in the pyrolysed cork powder was calculated - see Table 4. It can be seen that for CaAc_3 the ratio corresponds - within experimental error - with the theoretical value of 0.17 (Ca:C 1:6); this would imply that all calcium dissolved in solution is successfully infiltrated and converted into $\mathrm{CaCO}_{3}$ (i.e. $100 \%$ yield). A much lower value was found for CaLac_3 (0.11, corresponding to about $65 \%$ yield), in agreement with the presence of the unreacted carbon from cork, shown by the TGA data.

\subsection{Surface area and porosity}

To correlate the preparation conditions with the porosity of the powders, surface area measurements were performed on CaAc_3 and CaLac_3; this feature is crucial for applications in environment remediation (i.e. adsorption/removal of pollutants). The adsorption/ desorption isotherms are shown in Fig. 7(a), and both are type II isotherms, indicating initial monolayer coverage, followed by multilayer coverage in the "flatter" midsection.

The hysteresis appears to be a mixture of $\mathrm{H} 3$ and $\mathrm{H} 4$ types, both of

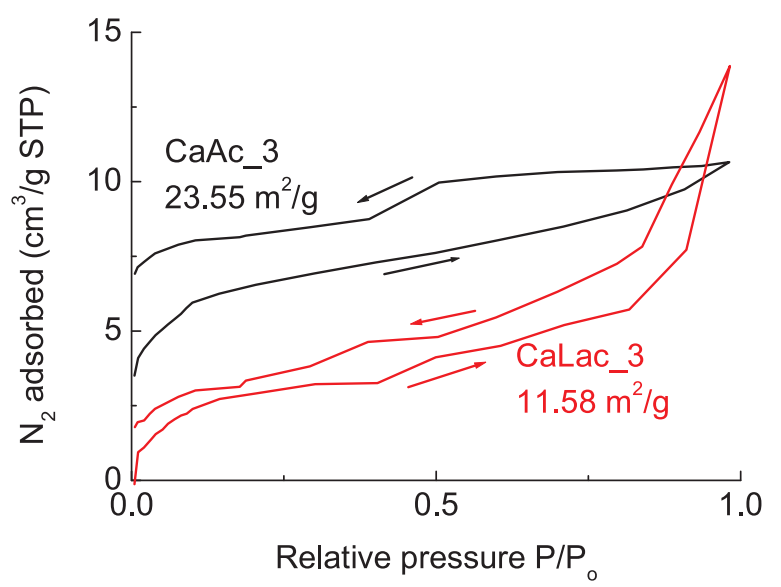

Fig. 7. BET adsorption/desorption isotherms and calculated surface areas of CaAc_3 and CaLac_3. 
which are due to the filling of pores. H3 is due to the filling of macropores (i.e., the cells of the cork structure), while $\mathrm{H} 4$ is due to the filling of micropores/mesopores, and is often found in mesoporous zeolites and micro-mesoporous carbons [39]. However, there are significant differences between the two samples; in fact, the BET surface area values for CaAc_3 and CaLac_3 were 23.55 and $11.58 \mathrm{~m}^{2} / \mathrm{g}$, respectively. Other $\mathrm{CaCO}_{3}$-based materials derived from natural templates showed lower surface area values. When spruce root was used, for instance, a SSA value of $8 \mathrm{~m}^{2} / \mathrm{g}$ was measured [40]; with lotus root, on the other hand, an even lower value was reported $\left(6 \mathrm{~m}^{2} / \mathrm{g}\right)$ [17]. The use of ginko leaves led to higher surface area $\left(13.42 \mathrm{~m}^{2} / \mathrm{g}\right)$ [41], which is still close to half of that obtained in the present study with the sample CaAc_3.

Considering the shape of the hysteresis loop, it can be observed that it is much narrower for CaLac_3, indicating that overall less adsorption due to porosity is occurring, whereas the greater extent of both hysteresis and upturn, and higher relative pressure values, indicate a greater influence of the macroporosity (more of an $\mathrm{H} 3$ type hysteresis) in CaLac_3. The t-plot indicates a minimal effect of microporosity on this sample, with virtually all of the surface area being external. On the other hand, CaAc_3 shows a more H4 like hysteresis, with a greater influence of microporosity at low relative pressures, and the t-plot indicates an external surface area of $16.26 \mathrm{~m}^{2} / \mathrm{g}$ and an internal microporosity of $7.29 \mathrm{~m}^{2} / \mathrm{g}$. This difference in internal microporosity and increased surface area available in CaAc_3 possibly explains the persistence of the precursor salt phase up to $500{ }^{\circ} \mathrm{C}$, maintained internally within the micropores/mesopores of this sample. From the $\mathrm{BJH}$ (Barrett, Joyner and Halenda) analysis of pore size and volume distributions, the average mesopore size is $66-101 \AA$ for CaLac_3, but only 36-39 $\AA$ for CaAc_3, with the mesopore volume distribution peaking at $\sim 150 \AA$ for CaLac_3 and $\sim 40 \AA$ for CaAc_3.

These results indicate that the sample made with calcium acetate possesses a larger specific surface area and a greater degree of meso-/ microporosity with a smaller average mesopore diameter. These data confirm that the nature of the counter-ion can affect various characteristics of the prepared samples, even if the phase composition is the same.

Overall these data show that the use of the calcium acetate is more suitable for use as a precursor for the preparation of porous biomimetic $\mathrm{CaCO}_{3}$. Indeed sample $\mathbf{C a A c} 3$ exhibits the highest surface area ever reported for $\mathrm{CaCO}_{3}$ derived from a plant-based template; moreover, it shows a dual scale, hierarchical porosity, with both macropores (micron scale) and micropores/mesopores (nanoscale).

These characteristics make this methodology appropriate to prepare $\mathrm{CaCO}_{3}$ for environment remediation. As future work, these materials will be tested for the removal of model contaminants, i.e. heavy metals as well as organic emerging pollutants.

\section{Conclusions}

Calcium carbonate was successfully prepared by using a sustainable template agent - waste cork powder. The process consisted of pyrolysis of cork, followed by infiltration with appropriate calcium salt and a successive thermal treatment, either in the air or in an inert $\left(\mathrm{N}_{2}\right)$ atmosphere. Different experimental conditions were tested to obtain the material with the optimal characteristics. Results showed that the nature of the calcium salt and the concentration of the infiltrating solutions played a key role in the morphology, the porosity and the surface area characteristics of the prepared material. Indeed, the powders prepared with calcium acetate followed by pyrolysis at $700{ }^{\circ} \mathrm{C}$ for 30 min showed the best features, with all infiltrated calcium reacting to form $\mathrm{CaCO}_{3}$ and with the characteristic 3D cork structure being well preserved in the $\mathrm{CaCO}_{3}$ ecoceramic product. The biomimetic $\mathrm{CaCO}_{3}$ produced with acetate salts had a higher surface area (the highest ever reported for materials prepared from a plant-based template), and also exhibited a dual scale, hierarchical porosity, with significant quantities of both macropores (micron scale hexagonal cells) and micropores/ mesopores (nanoscale pores within the cell walls).

The porous biomorphic calcium carbonate materials prepared with this method could be used for environmental remediation, or as the basis for lightweight or thermally insulating construction materials. They could also be employed as starting materials to prepare porous biomorphic calcium phosphate-based materials usable as bone substitutes and bioimplants.

\section{Authors contribution}

All authors contributed to the interpretation and discussion of the data, the writing of the paper and its revision.

Francesca Scalera performed the experiments of infiltrations and thermal treatments.

Luigi Carbone gave support for the work in the laboratory, particularly for the thermal treatments.

Simona Bettini performed the FTIR and Raman analysis.

Robert Pullar performed the XRD, SEM and surface area analysis.

Clara Piccirillo performed the TGA analysis and designed the experimental work.

\section{Declaration of Competing Interest}

The authors declare that they have no known competing financial interests or personal relationships that could have appeared to influence the work reported in this paper.

\section{Acknowledgments}

This work was developed within the project HApECOrk, funded by Fondazione con il Sud (project 2015-0243). R.C. Pullar wishes to thank National funding provided by FCT (Fundação para a Ciência e a Tecnologia, Portugal), in the frame of the H2CORK project, grant no. PTDC/CTM-ENE/6762/2014, as well as FCT grant IF/00681/2015, and the project CICECO-Aveiro Institute of Materials, FCT Ref. UID/CTM/ $50011 / 2019$, financed by national funds through the FCT/MCTES. L. Carbone acknowledges financial support by the Italian Ministry of Education, University and Research through the Research Project TECNOMED, "Research Program for the application of Nanotechnology and Photonics to Precision Medicine", (CUP: B83B17000010001). The authors would like to thank Dr. David M. Tobaldi for his help in the interpretation of the XRD data, Dr. Antonio Qualtieri for his assistance in SEM analysis and Amorim Cork Composites for providing the cork samples.

\section{Appendix A. Supplementary data}

Supplementary material related to this article can be found, in the online version, at doi:https://doi.org/10.1016/j.jece.2019.103594.

\section{References}

[1] T. Chen, P. Shi, Y. Li, J. Zhang, T. Duan, Y. Yu, J. Zhou, W J. Zhu, Crystallization of calcium carbonate mineral with hierarchical structures regulated by silk fibroin in microbial mineralization system, Cryst. Growth 439 (2018) 51-57.

[2] R. Sun, P. Zhang, E. Bajnóczi, A. Neagu, C.W. Tai, I. Persson, M. Strømme, O. Cheung, Amorphous calcium carbonate constructed from nanoparticles aggregates with unprecedented surface area and mesoporosity, ACS Appl. Mater. Interf. 10 (2018) 21556-21564.

[3] C.B. Tovani, T.M. Oliveira, A. Gloter, A.P. Ramos, $\mathrm{Sr}^{2+}$-substituted $\mathrm{CaCO}_{3}$ nanorods: impact on the structure and bioactivity, Cryst. Growth Des. 18 (2018) 2932-2940.

[4] R. Liu, B. Lian, Immobilisation of Cd(II) on biogenic and abiotic calcium carbonate, J. Haz. Mater. 378 (2019) 120707.

[5] K. Ma, L. Cui, Y. Dong, T. Wang, C. Da, G.J. Hirasaki, S.B. Biswal, Adsorption of cationinc and anionic surfactants on natural and synthetic carbonate materials, J. Coll. Interf. Sci. 408 (2013) 164-172.

[6] X. Ma, L. Li, L. Yang, C. Su, K. Wang, S. Yuan, J. Zhou, Adsorption of heavy metal 
ions using hierarchical $\mathrm{CaCO}_{3}$-maltose meso/macroporous hybrid materials: adsorption isotherms and kinetic studies, J. Haz. Mater. 209-210 (2012) 467-477.

[7] S.N. Muhammad, F.M. Kusin, M.S. Md Zahar, F. Mohamat Yusuff, N. Halimoon, Passive bioremediation technology incorporating lignocellulosic spent mushroom compost and limestone for metal- and sulphate-rich drainage, Environ. Technol. 38 (2017) 2003-2012.

[8] E. Iakoleva, M. Sillampää, P. Maydannik, J.T. Liu, S. Allen, A.B. Albadarin, C. Mangwandi, Manufactruing of novel low-cost adsorbent: co-granulation of limestone and coffee waste, J. Environ. Manag. 203 (2017) 853-860.

[9] H. Eufinger, C. Rasche, J. Lehmbrock, M. Wehmoller, S. Weihle, I. Schmitz, C. Schiller, M. Epple, Performance of functionally graded implants of polylactides and calcium phosphate/calcium carbonate in an ovine model for computer assisted craniectomy and cranioplasty, Biomaterial 28 (2007) 475-485.

[10] N. Mohan, R. Palangadan, F.B. Fernandez, H. Varma, Preparation of hydroxyapatite porous scaffold from a "coral-like" synthetic inorganic precursor for use as a bone substitute and a drug delivery vehicle, Mater. Sci. Eng. C 92 (2018) 329-337.

[11] M. Wang, S. Wu, J. Guo, X. Zhang, Y. Yang, F. Chen, R.J. Zhu, Immobilization of cadmium by hydroxyapatite converted from microbial precipitated calcite, J. Hazard. Mater. 366 (2019) 684-693.

[12] Y.P. Guo, T. Long, S. Tang, Y.J. Guoa, Z.A. Zhu, Hydrothermal fabrication of magnetic mesoporous carbonated hydroxyapatite microspheres: biocompatibility, osteoconductivity, drug delivery property and bactericidal property, J. Mater. Chem. B 2 (2014) 2899-2909.

[13] M. Li, Y. Chen, L.B. Mao, Y. Jiang, M.F. Liu, Q. Huang, Z. Yu, S. Wang, S.H. Yu, C. Lin, X.Y. Liu, H. Colfen, Seeded mineralization leads to hierarchical $\mathrm{CaCO}_{3}$ thin coatings on fibers for oil/water separation applications, Langmuir 34 (2018) 2942-2951.

[14] Z. Wu, C. Shi, K.H. Khayat, Multi-scale investigation of microstructure, fiber pullout behaviour, and mechanical properties of ultra-high performance concrete with nano- $\mathrm{CaCO}_{3}$ particles, Cem. Concr. Compos. 86 (2018) 255-265.

[15] J. Ramírez-Rico, J. Martínez-Fernandez, M. Singh, Biomorphic ceramics from woodderived precursors, Int. Mater. Rev. 62 (2017) 465-485.

[16] M. Singh, J. Martínez-Fernández, A.R. Arellano-López, Environmentally conscious ceramics (ecoceramics) from natural wood precursors, Curr. Opin. Solid State Mater. Sci. 7 (2003) 247-254.

[17] J.Y. Chen, C.Y. Yang, P.Y. Chen, Synthesis of hierarchically porous structured $\mathrm{CaCO}_{3}$ and $\mathrm{TiO}_{2}$ replicas by sol-gel method using lotus root as template, Mater. Sci. Eng. C 67 (2016) 85-97.

[18] A. Tampieri, S. Sprio, A. Ruffini, G. Celotti, I.G. Lesci, N. Roveri, From wood to bone: multi-step process to convert wood hierarchical structure into biomimetic hydroxyapatite scaffolds for bone tissue engineering, J. Mater. Chem. 19 (2003) 4973-4980.

[19] H. Pereira, The rationale behind cork properties: a review of structure and chemistry, Bioresour. Technol. Rep. 10 (2015) 1-23.

[20] M. Demertzi, J. Amaral, P.L. Arroja, A.C. Dias, Carbon footprint simulation model for the cork oak sector, Sci. Total Environ. 566-567 (2016) 499-511.

[21] R.C. Pullar, P. Marques, J. Amaral, J.A. Labrincha, Magnetic wood-based biomorphic $\mathrm{Sr}_{3} \mathrm{Co}_{2} \mathrm{Fe}_{24} \mathrm{O}_{41}$ Z-type hexaferrite ecoceramics made from cork templates, Mater. Des. 82 (2015) 297-303.

[22] R.C. Pullar, R.M. Novais, Ecoceramics - cork-based biomimetic ceramic 3-DOM foams, Mater. Today 20 (2017) 45-46.

[23] V.O. Yukhymchuk, V.S. Kieslow, M.Y. Valakh, M.A. Skoryk, A.G. Rozhin, S.A. Kulinich, A.E. Belyaev, Biomorphous SiC ceramics prepared from cork oak as precursor, J. Phys. Chem. Sol. 91 (2016) 145-151.
[24] A. Quarta, R.M. Novais, S. Bettini, M. Iafisco, R.C. Pullar, C. Piccirillo, A sustainable multi-function biomorphic material for pollution remediation or UV absorption: aerosol assisted preparation of highly porous $\mathrm{ZnO}$-based materials from cork templates, J. Environ. Chem. Eng. 7 (2019) 102936.

[25] R.M. Novais, R.C. Pullar, Comparison of low and high pressure infiltration regimes on the density and highly porous microstructure of ceria ecoceramics made from sustainable cork templates, J. Eur. Ceram. Soc. 39 (2019) 1287-1296.

[26] T. Chen, P. Shi, Y. Li, T. Duan, Y. Yu, X. Li, W. Zhu, Biomineralization of varied calcium carbonate crystal by synergistic effect of silk fibroin/magnesium ions in a microbial system, Cryst. Eng. Comm. 20 (2018) 2366-2373.

[27] M. Khachani, A. El Hamidi, M. Halim, S.J. Arsalene, Non-isothermal kinetic and thermodynamic studies of the dehydroxylation process of synthetic calcium hydroxide $\mathrm{Ca}(\mathrm{OH})_{2}$, Mater. Environ. Sci. 5 (2014) 615-624.

[28] Y. Hattori, R. Kojima, K. Sagisaka, M. Umeda, T. Tanaka, A. Kondo, T. Iiyama, M. Kumura, H. Fujimoto, H. Touhara, Preparation and formation mechanism of porous carbon nanosheets by thermal decomposition of polyvinyl alcohol films impregnated with zinc (II) salt and nitrate ions, Sol. State Sci. 65 (2017) 33-40.

[29] A.W. Musumeci, R.L. Frost, E.R. Waclawic, Spectroscopic study of the mineral paceite (calcium acetate), Spectrochim. Acta A 67 (2017) 649-661.

[30] S.E. Lambert, D.G. Randall, Manufacturing bio-bricks using microbial indiced calcium carbonate precipitation and human urine, Water Res. 160 (2019) 158-166.

[31] C. Piccirillo, I.S. Moreira, R.M. Novais, A.J.S. Fernandes, R.C. Pullar, P.M.L. Castro, Biphasic apatite-carbon materials derived from pyrolysed fish bones for effective adsorption of persistent pollutants and heavy metals, J. Environ. Chem. Eng. 5 (2017) 4884-4894.

[32] L. Chávez-Guerrero, J.A. Salinas-Montelongo, A. Esquivias-Ferro, A simple method to obtain purified $\mathrm{CaCO}_{3}$ using fly ash as a raw material, Mater. Lett. 211 (2018) 220-223.

[33] E. Podstawka, M. Światlowska, E. Borowiec, L.M. Proniewicz, Food additive characterization by infrared, Raman, and surface-enhanced Raman spectroscopies, J. Raman Spectrosc. 38 (2007) 356-363.

[34] R. Selvaraju, A. Raja, G. Thiruppathi, Chemical composition and binary mixture of human urinary stones using FT-Raman spectroscopy method, Spectrochim. Acta A 114 (2013) 650-657.

[35] D. Shan, S. Wang, H. Xue, S. Cosnier, Direct electrochemistry and electrocatalysis of hemoglobin entrapped in composite matrix based on chitosan and $\mathrm{CaCO}_{3}$ nanoparticles, Electrochem. Comm. 9 (2007) 529-534.

[36] M.E.I. Saraya, H.H.A.L. Rokbaa, Preparation of vaterite calcium carbonate in the form of spherical nano-size particles with the aid of polycarboxylate superplasticizer as capping agent, Amer. J. Nanomater. 4 (2016) 44-51.

[37] R.M. Silverstein, F.X. Webster, D.J. Kiemle, Spectrometric Identification of Organic Compounds, $7^{\text {th }}$ ed., John Wiley \& Sons Inc., NJ, US, 2005.

[38] L. Zhao, Y. Zhang, Y. Miao, L. Nie, Controlled synthesis, characterization and application of hydrophobic calcium carbonate nanoparticles in PVC, Powder Technol. 288 (2016) 184-190.

[39] M. Thommes, K. Kaneko, A.V. Neimark, J.P. Olivier, F. Rodriguez-Reinoso, J. Rouquerol, K.S.W. Sing, Physisorption of gases, with special reference to the evaluation of surface area and pore size distribution (IUPAC Technical Report), Pure Appl. Chem. 87 (2015) 1051-1069.

[40] S. Klaithong, D. Van Opdenbosch, C. Zollfrank, J. Plank, Preparation of $\mathrm{CaCO}_{3}$ and $\mathrm{CaO}$ replicas retaining the hierarchical structure of spruce wood, Zeitsch. Natur. 68 (2013) 533-538.

[41] X. Peng, T. Cheng, M. Cheng, J. Wang, X. Zhang, Hierarchically porous $\mathrm{CaCO}_{3}$ monoliths prepared from leaf template, Mater. Lett. 129 (2014) 198-201. 